рота є іригація. Нами було обстежено загалом 90 осіб. Вік пацієнтів варіював від 40-60 років. 3 них 40 чоловік та 50 жінок. Аналізуючи значення показника білкових фракталів, а саме площа, ми оцінили та підтвердили гігієнічний стан ротової порожнини у осіб які використували ортопедичні конструкції. Застосування методу іригації тканин пародонта для незнімних ортопедичних конструкцій призводить до зменшення відсоткової частини площі білкових фракталів цифрових зразків кристалографії. Результати підтверджені статистичними і клінічними даними.

Ключові слова: мікроскопічна кристалографія, іригація, порожнина рота, пародонт, металокерамічні незнімні ортопедичні конструкції.

Стаття надійшла 24.09.2019 p. ирригация. Нами было обследовано 90 человек. Возраст пациентов варьировал от 40-60 лет. Из них 40 мужчин и 50 женщин. Анализируя значение показателя белковых фракталов, а именно площадь, мы оценили и подтвердили гигиеническое состояние полости рта у лиц которые использовали ортопедические конструкции. Применение метода ирригации тканей пародонта для несъемных ортопедических конструкций приводит к уменьшению процентной части площади белковых фракталов цифровых образцов кристаллографии. Результаты подтверждены статистическими и клиническими данными.

Ключевые слова: микроскопическая кристаллография, ирригация, полость рта, пародонт, металлокерамические несъемные ортопедические конструкции.

Рецензент Аветіков Д.С.

DOI 10.26724/2079-8334-2020-3-73-120-125

UDC 340.66:617.58 - 001

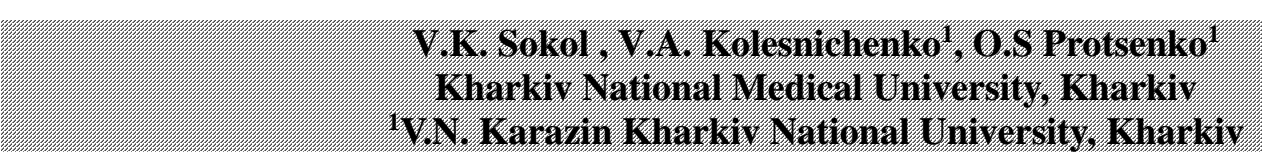

\title{
RETROSPECTIVE ANALYSIS OF PRIMARY FORENSIC MEDICAL EXAMINATIONS OF THE LOWER EXTREMITIES MECHANICAL TRAUMA
}

e-mail: sokol_vk@ukr.net

The purpose of the study was to perform a retrospective analysis of primary forensic medical examinations that established moderate severity of bodily injuries in victims with mechanical injuries of lower extremities. The study revealed the

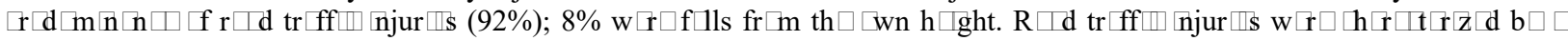

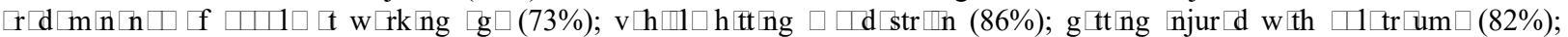

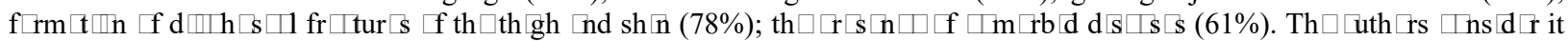
necessary to revise the existing and to substantiate new medical criteria for determining the severity of bodily injury, taking into account the features of connective and muscle tissues reparative regeneration. traffic injury.

Key words: mechanical trauma of the lower extremities, forensic medical examination, fractures of long bones, road

The work is a fragment of the research project "Forensic substantiation of morpho-clinical criteria for expert assessment of bodily injuries, determination of limitation period and cause of death", state registration No. $0118 U 000951$.

Forensic medical examination of living individuals is the most common type of expert activity. Establishment of damages and evaluation of their severity, in order of frequency, occupies the 1st place in forensic practice and is carried out both in criminal and civil proceedings [4]. According to data obtained from Kharkiv Regional Bureau of Forensic Medical Examination (KRBFME), over the last 5 years, the number of examinations of living individuals has increased from $83.7 \%$ in 2015 to $91.2 \%$ in 2019 (compared to all examinations and examinations of victims). Numerous works were dedicated to the examination of living persons, in particular, to the injuries' severity determination $[1,3,15]$.

Mechanical trauma of the lower extremities leads to damage to both soft tissues (tendons, ligaments, fascia, articular bag, sarcolemma and perimisia of muscle fibers, etc.) and supportive (bone, cartilage) types of connective tissue [11]. Each of them has a different resistance to the traumatic factor. Accordingly, the standard terms of reparative regeneration, after mechanical damage to each type of connective tissue, varies drastically - from 3-5 weeks in cases of tendon ruptures, up to 4-5 months (without callus remodeling) in cases of long tubular bones' fractures.

It should be noted that traumatic diaphyseal fractures of long tubular bones are accompanied by ruptures of intraosseous vessels, damage to fascia, ruptures and imbibition of muscle fibers. That can lead to the development of persistent contractures of adjacent (to a fracture zone) joints, regardless of the treatment method (surgical or conservative) [11]. In addition, metaepiphyseal fractures are also accompanied by ruptures of periarticular tissues (joint bag, ligaments, muscle tendons), damage to the hyaline articular cartilage, development of hemarthrosis with the formation of post-traumatic contractures of the injured joint [10]. In this regard, the terms of callus formation [6], and, especially, the periods of the rehabilitation in patients with fractures of long tubular bones [7], can significantly exceed the recovery time after isolated (especially partial) ruptures of ligaments or tendons. 
Determining the severity of bodily harm, in particular, after a mechanical injury to the lower extremities, which is not life-threatening, is carried out in accordance with paragraphs 2.2.1 of "Rules for the forensic medical determination of bodily harm severity" in the Order No. 6 of the Ministry of Health of Ukraine dated 01/17/95. The main criterion, in these cases, is the duration of a health disorder for a period of 21 days, the excess of which permits the expert to evaluate them as the moderate bodily harm. Based on this, injuries that are not comparable by their nature, the duration of the treatment, and, in some cases, their outcome, are evaluated by the same criteria: insulated rupture of the periarticular ligament (for example, rupture of medial collateral ligament of the knee joint) and the intraarticular fracture (for example, tibial epimetaphysis) with displacement. We presume that evaluation of the bodily injuries severity during a forensic medical examination of non-life-threatening mechanical injuries of the lower extremities should be justified basing on the objectively established fact of a violation in the structure and function of the body (in particular, musculoskeletal system) mainly in cases of damage outcomes, rather than basing on the formal duration of hospital stay and the term of outpatient treatment.

The purpose of the study was to perform a retrospective analysis of primary forensic medical examinations that established moderate severity of bodily injuries in the short post-traumatic period in victims with mechanical injuries of lower extremities. This analysis is aimed to clarify the nature of the lower extremities damage.

Material and methods. Study design is a retrospective cohort study.

Material of the study was the total of 100 reports on primary forensic medical examinations of victims with moderate severity of bodily injuries resulting from mechanical trauma to the lower extremities. In all cases, an expert assessment was carried out in the Kharkiv Regional Bureau of Forensic Medical Examination (KRBFME), within a period of not more than 1 month after an injury. Reports of primary forensic medical examinations were selected by random sampling, for the period February - June 2018.

Inclusion criteria - isolated ruptures of soft tissues (muscles, tendons, ligaments, menisci of the knee joint) of the lower extremities, isolated fractures, dislocations and fractures with dislocations of the femur or shin bones, multiple and combined non-life-threatening injuries, in which mechanical trauma of lower extremities prevailed, which led to moderate severity of bodily injury and which were assessed no later than in 1 month from the day of injury.

Exclusion criteria: isolated mechanical trauma of lower extremities, as well as multiple or combined injuries, which were regarded as light or severe injuries, or were performed in terms exceeding 1 month after injury.

Research methods were the retrospective analysis, statistical method.

When carrying out a retrospective analysis, the following indices were studied: trauma mechanism; type of injury (open, closed); the nature of the injury (isolated, multiple, combined); the nature of damage to the lower extremities tissues (tears of soft tissues: menisci, ligaments of the knee and ankle joints; fractures of the femur and lower leg bones); nature of the fracture (medial / lateral fractures of the femoral neck, transtrochanteric fractures, diaphyseal fractures, epimetaphysis fractures of the distal femur / proximal tibia, fractures of the medial / lateral ankle); the presence of dislocation / subluxation of the hip / knee / ankle joints. In the case of road traffic injuries, mechanical injuries of the lower extremities were identified in active (driver) and passive (passenger, pedestrian) road users.

When assessing the somatic status of the victims, the presence of comorbid conditions was taken into account: coronary artery disease, hypertonic disease, angina pectoris, obesity, diabetes mellitus, cholelithiasis, chronic gastroduodenitis.

Data processing was performed using descriptive statistics. The average age of the victims was determined by the formula $\mathrm{M} \pm \mathrm{m}$, where $\mathrm{M}$ is the arithmetic mean, $\mathrm{m}$ is the standard error of the mean.

Results of the study and their discussion. The results of the analysis on the parameters of lower extremities' mechanical trauma, which, according to the results of the primary forensic medical examinations was accompanied by moderate bodily injuries, made it possible to establish the following.

The mean age of the victims was $44.0 \pm 17.8$ years (18-81 years). The largest number of victims was at the working age of 18-60 years old $-73 \%$ (73/100); of injured older persons (61-81 years old) there were $27 \%(27 / 100)$. There was a slight prevalence of males (53\% of 100 patients), which in relation of the men to women ratio was 1.1: 1 (table 1).

More than half of the victims (61\% of 100 patients) had comorbid diseases. The most common were hypertension ( $23 \%$ of 100 patients), obesity (15\% of 100 patients) and coronary heart disease (11\% of 100 patients). Diseases of the gastrointestinal tract were observed much less frequently (chronic gastroduodenitis and cholelithiasis at 3\% (3/100)). Only 1 victim out of 100 cases (1\%) had angina pectoris (table 1).

Injuries were generally caused by traffic accidents - 92\% (92/100). Among other mechanisms of injury, there were: fallings from the own height with a rotated tibia $(7 \% ; 7 / 100)$ or foot $(1 \% ; 1 / 100)$. Isolated ruptures of the periarticular ligaments of the knee and ankle joints, which resulted in moderate bodily 
injuries, were observed much less frequently among mechanical injuries of lower extremities $-6 \%(6 / 100)$ and $2 \%(2 / 100)$, respectively, and formed as a result of a fall from a height of their own growth.

Distribution by age, gender, frequency of comorbid diseases in patients with moderate degree of bodily injuries due to mechanical injuries of lower extremities

\begin{tabular}{|c|c|c|c|c|c|}
\hline \multirow{2}{*}{ Parameters } & \multicolumn{2}{|c|}{ Number of victims $(n=100)$} & \multirow{2}{*}{ Parameters } & \multicolumn{2}{|c|}{ Number of victims $(n=100)$} \\
\hline & abs. & $\%$ & & abs. & $\%$ \\
\hline \multicolumn{3}{|c|}{ Age } & Comorbid diseases: & 61 & 61 \\
\hline 18 - 60 years old & 73 & 73 & - hypertonic disease & 23 & 23 \\
\hline $61-75$ years old & 16 & 16 & - obesity & 15 & 15 \\
\hline over 76 years old & 11 & 11 & - coronary artery disease & 11 & 11 \\
\hline \multicolumn{3}{|c|}{ Mean age $44,0 \pm 17,8$ years old } & - diabetes mellitus & 5 & 5 \\
\hline \multicolumn{3}{|c|}{ 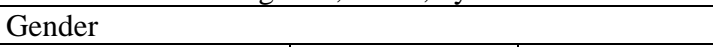 } & - chronic gastroduodenitis & 3 & 3 \\
\hline - male & 53 & 53 & - cholelithiasis & 3 & 3 \\
\hline - female & 47 & 47 & - angina pectoris & 1 & 1 \\
\hline
\end{tabular}

To clarify the mechanism of road traffic injury, all 92 victims of road accidents were taken as $100 \%$. It was found that the most often, by collision of person with a moving car - 86\% (79/92). Damage to a passenger $(7 \% ; 6 / 92)$ and a driver $(3 \% ; 3 / 92)$ in a passenger compartment, a collision of a person with a moving motorbike $(2 \% ; 2 / 92)$, and damage from a driver falling out of a moving motorcycle $(1 \% ; 1 / 92)$ were much less common (table 2). Thus, active road users (drivers) participated in 4\% (4/92) of road accidents, passive participants (pedestrians and passengers) - in 96\% (88/92).

Table 2

Nature of injuries and road traffic injury mechanism in patients with moderate bodily injuries

\begin{tabular}{|l|c|c|}
\hline \multicolumn{1}{|c|}{ Parameters } & \multicolumn{2}{c|}{ Number of victims $(\mathrm{n}=92)$} \\
\cline { 2 - 3 } & abs. & \multicolumn{2}{c|}{} \\
\hline Polytrauma & 75 & 72 \\
\hline - combined injury & 66 & 10 \\
\hline - multiple fractures & 9 & 18 \\
\hline Isolated mechanical injury & 17 & 29 \\
\hline Open damage & 27 & 71 \\
\hline Closed damage & 65 & \multicolumn{2}{c|}{86} \\
\hline Injury mechanism & \multicolumn{2}{c|}{} \\
\hline - collision of a man with a moving car & 79 & 3 \\
\hline - damage to a passenger in a car cabin & 6 & 2 \\
\hline - damage to the driver in the car cab & 3 & \\
\hline - damage from a driver falling out of a moving motorcycle & 2 & \\
\hline
\end{tabular}

According to our material, the mean age of the road accidents victims was $41.5 \pm 18.8$ years; persons of working age prevailed ( $73 \%$ of 92 patients). The ratio of male to female was 1.1:1.

As it is noted above, according to our material all the long bones fractures of the lower extremities were obtained as a result of road traffic accidents (RTAs), which were 92\% (92/100) of the lower extremities mechanical injuries. In this group of 92 patients as a result of a road traffic injury, predominantly combined injuries were observed $(72 \% ; 66 / 92)$ (table 2), in which bone fractures were the leading lesion; closed fractures predominated $(71 \% ; 65 / 92)$. Fracture of the femur and / or lower leg bones in all cases was accompanied by bruised and lacerated wounds, bruises, abrasions, and subcutaneous hematomas of the head, and/or trunk, and/or upper limbs. Closed head injury with a mild degree concussion of the brain was diagnosed in $23 \%$ (23/92) of cases. Also, in 3\% (3/92) of cases, closed fractures of the ribs were revealed; in one victim - self-healing dislocation of the humerus, in 3\% (3/92) - diaphyseal fractures of the forearm, in 7\% (7/92) distal radial bone fractures, in 2\% (2/92) - fractures of the ulna styloid process.

With multiple fractures of lower extremities $(10 \%$; 9/92), ipsilateral and contralateral fractures of the femur and tibia occurred with almost the same frequency - 4\% (4/92) and 3\% (3/92) of cases, respectively. In $2 \%$ of cases (2/92), a double fracture of the leg bones was revealed (table 3 ).

According to the nature of the damage, diaphyseal fractures of long bones predominated, which together accounted for 78\% (72/92) of the cases. Of these, femoral diaphysis fractures accounted for 32\% (29/92), diaphyseal fractures of the tibia - 47\% (42/92). Intra-articular fractures of various localization were formed in 26 injured in traffic accidents. In this case, the hip joint suffered less frequently than others: medial fractures of the femoral neck were recorded in 4\% (4/92) cases. Intra-articular fractures of the knee and ankle joints formed with the same frequency -11 observations: with damage to the distal femur epimetaphysis - 2\% (2/92), proximal tibia epimetaphysis - 10\% (9/92), internal / external ankle fracture $3 \%$ (3/92), both ankles - 9\% (8/92) (table 3).

According to the data of the primary forensic medical examinations that were studied, a road traffic pedestrian injury in a collision with a moving car $(78 \% ; 62 / 79)$ was noted in the houses courtyards. Another 2 
cases (out of 92) of a pedestrian injury in a collision with a moving scooter were registered in a city road near a traffic light. Other accidents involving collisions of moving cars (9 out of 92) occurred at unregulated intersections of secondary urban roads. A road traffic injury with a passenger who fell out of a motorcycle that started moving ( 2 out of 92) was observed in rural roads. In all these cases, road accidents were characterized by a low vehicle speed (30-40 km/h) and, accordingly, a relatively small amount of kinetic energy absorbed by the body of the injured road user. Due to this circumstance, the injuries received by the victims of the road accident were harmless to life and were characterized by a moderate severity of bodily injuries.

Nature of long bones damage to the lower extremities due to mechanical injuries with bodily

Table 3 injuries of moderate severity

\begin{tabular}{|l|c|c|}
\hline \multicolumn{1}{|c|}{ Nature of damage } & \multicolumn{2}{c|}{ Number of victims (n=92) } \\
\cline { 2 - 3 } & abs. & 4 \\
\hline Medial fractures of femoral neck & 4 & 1 \\
\hline Transtrochanteric fracture & 1 & 32 \\
\hline Femoral diaphysis fracture & 29 & 2 \\
\hline Fracture of the distal femur epimetaphysis & 2 & 10 \\
\hline Fracture of the proximal tibia epimetaphysis & 9 & 47 \\
\hline Diaphyseal fracture of the shin bone & 43 & 2 \\
\hline Double diaphyseal fracture of the tibia & 2 & 3 \\
\hline Fracture of the medial / lateral ankle & 3 & 9 \\
\hline Fracture of both ankles & 8 & \\
\hline
\end{tabular}

In pedestrians, damage to the integumentary system of the lower extremities occurred during the first phase of a collision of a car, at the moment the pedestrian's body touched the surface of the car in a collision, during which the victim received a strike. In the same phase, bumper fractures of the diaphysis of the femur or shin bones were formed, which had a transverse fracture plane and, as a rule, were finely splintered. Contusions, abrasions and subcutaneous hematomas of the head and extremities, as well as fractures and dislocations of the bones of the upper extremities occurred mainly when the victim fell onto the road surface or the side of the road from the height of the car hood (the third phase of collision). Damage to the integumentary system in the second phase of the collision (pedestrian falling onto the hood of a car) due to a relatively low kinetic energy of the collision was noted only in 4 (out of 79) victims.

For drivers and passengers of cars, bruises and abrasions of the head area (impact on the side glass), bruises of the chest area and fractures of the ribs (impact on the steering wheel), bruises, hematomas and abrasions of the knee and ankle area, intra-articular fractures of the knee and fractures of the ankles (impact on the dashboard). All injuries were sustained in the phase of collision of the body with parts and components of the car's cabin. It should be noted that in both pedestrian and intra-salon trauma, the victims did not reveal the classic specific stamp-damage of the integumentary system from impact on the protruding parts of the car. This fact is largely due to the modern design features of passenger cars - the absence of protruding parts.

The absence of specific stamp-damages in a modern car injury makes it difficult to reliably reproduce the mechanism and circumstances of an accident during a forensic medical examination. Thus, in one of the expert reports that were analyzed, the mechanism of the formation of a medial fracture of the femoral neck was not finally determined when differentiating between a high-energy fracture due to a pedestrian injury and a low-energy fracture as a result of falling from a height of victim's own growth.

In the studied acts of primary forensic medical examinations (within 1 month after injury), the outcomes of fractures of the lower extremities are not presented, since at such times the union of fractures of the femur or tibia cannot be achieved, especially in patients with polytrauma. With respect to medical criteria, assessment of the treatment outcome is the normal course of the post-traumatic period. However, during a forensic examination, the body's response in the acute period of injury or at rehabilitation stages can prolong the duration of a health disorder - one of main criteria for assessing the bodily harm severity. We believe that there is an urgent need to review the current medical criteria for the forensic medical assessment of bodily injuries in mechanical injuries of musculoskeletal system and lower limbs in particular, which take into account the length of stay in inpatient or outpatient care. It is necessary to determine objective medical criteria that take into account current knowledge about the mechanism and nature of injuries, the features of the consolidation of various fracture types, the impact of concomitant injuries and comorbid diseases on reparative regeneration processes of connective and muscle tissues, the duration and content of the rehabilitation period.

One of this study results was the fact road traffic accidents significant prevalence in the structure of criminal injury. These data are consistent with the WHO statistics on road traffic injuries, which are one 
of the most important medical, social and economic problems in the world. According to the WHO, every 5 min one person becomes disabled in the roads of the world [7]. Road traffic injuries are $35.4 \%$ of all types of injuries, they occupy the first place among the causes of death from mechanical damage, they are one of the main reasons for disabled citizens of working age and cost most countries $3 \%$ of their gross domestic product [15].

The data cited in the literature regarding the frequency of injury to men and women as a result of an accident are heterogeneous. Results close to the data of our study were obtained in the study of nonlethal car injuries with damage to long bones caused by collision with a car: 1.3:1 [1], 1.6:1 [2]. In contrast, in studies on the structure of accidents taking into account fatal outcomes, a significant predominance of males is revealed: 6:1 [5], 8.3:1 [9].

It should also be noted the presence of comorbid diseases, which were detected in more than half of the victims $(61 \% ; 61 / 100)$ (table 2). Although chronic diseases were not taken into account when conducting a forensic medical examination of people who had suffered from mechanical injuries of lower extremities, their presence, especially diabetes mellitus, obesity, arterial hypertension, can significantly affect the rate of formation and quality of callus and is a risk factor for delayed consolidation and nonfusion fracture [14].

Pedestrian collision in our study was the most frequent type of road accident (86\%; 79/92), which coincides with the literature data [8]. Despite the fact that in most cases the pedestrian collision with a passenger car was characterized by a low speed of movement of the car, the main type of damage was polytrauma. In such cases, polytrauma is accompanied by a systemic inflammatory response syndrome (SIRS) [13], what has a negative effect on the processes of reparative regeneration of bone tissue [6]. It should also be noted that $85 \%$ of patients with combined trauma with injuries of the musculoskeletal system [12] and, as a rule, all patients with fractures of long bones of the lower extremities, regardless of the method of treatment (surgical, conservative), need rehabilitation.

Prospects for further research - in order to justify medical criteria for determining the severity of bodily damages during mechanical injury of long bones, a retrospective analysis of the commission of forensic medical examinations of injuries seems promising.

\section{Condusions}

1. In the structure of mechanical injuries of the lower extremities in victims with moderate degree bodily injuries, the leading injuries were fractures of the femur and lower leg bones (92\%) resulting from road traffic injuries.

2. In victims of road traffic injury in $61 \%$ of cases concomitant comorbid diseases were detected. In the structure of fractures, diaphyseal fractures prevailed - 79\%, intra-articular fractures of the hip, knee and ankle joints formed in 27\%; in $82 \%$ polytrauma was detected. The duration of a health disorder with these injuries will significantly exceed the period of 21 days, a priori established as the boundary between bodily injuries of mild to moderate severity.

3. We consider it is necessary to justify new medical criteria for assessing the severity of bodily injuries that will make it possible to objectively evaluate post-traumatic structural changes in the body and their functional consequences.

\section{Reterences}

1. Glinskyi SV. Sudebno-meditsinskaya otsenka naezda legkovogo avtomobilya v sluchayah neletalnoy travmi. Izbrannye voprosy sudebno-meditsinskoy ekspertizy. 2019;18:61-63 [in Russian]

2. Gurev SO, Yevdoshenko VP, Satsik SP. Kliniko-epidemiolohichna kharakterystyka masyvu postrazhdalykh iz poshkodzhennyamy dovhykh kistok unaslidok dorozhnyo-transportnykh prygod. Travma. 2014;15(5):27-30. [in Ukrainian]

3. Katerynchuk KV, Yukhymets IO. «Tilesni ushkodzhennya» chy «shkoda zdorovyu»: yurydychnyi ta sudovo-medychnyi pohlyady. Informatsiya i pravo. 2017; 2(21):133-143. [in Ukrainian]

4. Misaev AO, Seilkhanov KE, Surkov SV, Bokembaev NA, Amrenov TZh, Misaev AO. Dorozhno-transportnyi travmatizm. Chast 1: epidemiologia. Literaturnyi obzor. Nauka i zdravoohranenie. 2013; 6: 16-21. [in Russian]

5. Anantharaman VV, Logaraj M. Epidemiology of road traffic accidents (RTA) reported at a Tertiary Care Hospital in Chennai. Nat J Res Commun Med. 2015; 4(1):101-105.

6. Copuroglu C, Calori GM, Giannoudis PV. Fracture non-union: Who is at risk? Injury. 2013;44(11):1379-1382. DOI:https://doi.org/10.1016/j.injury.2013.08.003.

7. Global status report on road safety 2018. Geneva: World Health Organization. 2018; 424 p.

8. Goniewicz K, Goniewicz M, Pawłowski W, Lasota D. Epidemiology of road traffic accidents in adults. A systematic review. J Educ Health Sport. 2017;7(7):92-100.

9. Manna N, Mallik S, Mandal PK, Chakraborty D, SardarJC, Pritibikash H, Gupta SD. Epidemiological factors of road traffic accidents: a study in a tertiary care setting in India. J Pak Med Stud. 2013; 3(1):48-53.

10. Min W, Ding BC, Tejwani NC. Comparative functional outcome of AO/OTA type C distal humerus fractures: Open injuries do worse than closed fractures. J Trauma Acute Care Surg. 2012; 72(2):E27-E32. doi: 10.1097/TA.0b013e31821915ae.

11. Pfeifer R, Darwiche S, Kohut L, Billiar TR, Pape H-C. Cumulative Effects of Bone and Soft Tissue Injury on Systemic Inflammation: A Pilot Study. Clin Orthop Relat Res. 2013;471:2815-2821. doi:10.1007/s11999-013-2908-8.

12. Rouleau DM, Place A, Bérubé M, 
13. Laflamme YO, Feldman D. Rehabilitation after lower limb injury: development of a predictive score (RALLI score). Can J Surg. 2015;58(4):278-283. doi:10.1503/cjs.015014.

14. Singh R, Singh HK, Gupta SC, Kumar Y. Pattern, severity and circumtances of injuries sustained in road traffic accidents: a tertiary care hospital-based study. Indian J Commun Med [Internet]. 2014; 39(1):30. doi:10.4103/0970-0218.126353.

15. Tarazona-Santabalbina FJ, Belenguer-Varea A, Rovira-Daudi E, Salcedo-Mahiques E, Cuesta-Peredó D, Doménech-Pascua JR, et al. Early interdisciplinary hospital intervention for elderly patients with hip fractures: functional outcome and mortality. Clinics [Internet]. 2012;67(6) https://doi.org/10.6061/clinics/2012(06)02.

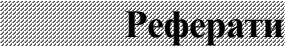 \\ РЕТРОСПЕКТИВНИЙ АНАЛІЗ ПЕРВИННИХ \\ СУДОВО-МЕДИЧНИХ ЕКСПЕРТИЗ ПРИ МЕХАНИЧНІЙ ТРАВМІ НИЖНІХ КІНЦІВОК \\ Сокол В.К., Колесніченко В.А., Проценко О.С. Мета роботи - ретроспективний аналіз первинних судово-медичних експертиз, в яких встановлено середню ступінь тяжкості тілесних ушкоджень у потерпілих з механічними травмами нижніх кінцівок. Виявлено переважання дорожньо-транспортної травми (92\%); в 8\% відбулося падіння з висоти власного зросту. Дорожньо-транспортна травма характеризувалася переважанням осіб працездатного віку (73\%); наїздом транспортного засобу на пішохода (86\%); отриманням політравми (82\%); утворенням діафізарних переломів стегна і гомілки (78\%); наявністю коморбідних захворювань $(61 \%)$. Автори вважають за необхідне перегляд існуючих і обгрунтування нових медичних критеріїв визначення ступеня тяжкості тілесних ушкоджень 3 урахуванням особливостей репаративної регенерації сполучної та м'язової тканини. \\ Ключові слова: механічна травма нижніх кінцівок, судово-медична експертиза, переломи довгих трубчастих кісток, дорожньо-транспортна травма.}

Стаття надійшла 2.09.2019 p.

\section{РЕТРОСПЕКТИВНЫЙ АНАЛИЗ ПЕРВИЧНЫХ СУДЕБНО-МЕДИЦИНСКИХ ЭКСПЕРТИЗ ПРИ МЕХАНИЧЕСКОЙ ТРАВМЕ НИЖНИХ КОНЕЧНОСТЕЙ}

Сокол В.К., Колесниченко В.А., Проценко О.С.

Цель работы - ретроспективный анализ первичных судебно-медицинских экспертиз, установивших среднюю степень тяжести телесных повреждений у потерпевших с механическими травмами нижних конечностей. Выявлено преобладание дорожно-транспортной травмы (92\%); в $8 \%$ произошло падение с высоты собственного роста. Дорожнотранспортная травма характеризовалась преобладанием лиц трудоспособного возраста (73\%); наездом транспортного средства на пешехода (86\%); получением политравмы (82\%); образованием диафизарных переломов бедра и голени (78\%); наличием коморбидных заболеваний (61\%). Авторы считают необходимым пересмотр существующих и обоснование новых медицинских критериев определения степени тяжести телесных повреждений с учетом особенностей репаративной регенерации соединительной и мышечной ткани.

Ключевые слова: механическая травма нижних конечностей, судебно-медицинская экспертиза, переломы длинных трубчатых костей, дорожно-транспортная травма. Рецензент Голованова I.А.

DOI 10.26724/2079-8334-2020-3-73-125-129

UDC 616.314.5 - 053.9

\section{X. Tawas

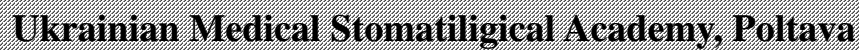

\section{THE MOST SIGNIFICANT MORPHOLOGICAL FEATURES OF THIRD MOLARS IN ADULT PERSONS ACCORDING TO ORTHOPANTOMOGRAPHY}

e-mail: roman_talash@ukr.net

The article presents a theoretical generalization and a new solution of the scientific problem, which consists in determining the morphological features of third molars according to orthopantomography. A literature review, the analysis results of the dentition orthopantomograms of persons in the first period of mature age, randomly selected in the clinic, are presented. A systematic analysis of the general visual representation of third molars' morphological features in people of mature age, was carried out based on orthopantomograms selection. Morphological features of third molars, forms of retention, types of dystopia, morphological differences between impacted and embedded third molars were established. The systematic approach used in the work permitted to put in order the variational polymorphism of anomalously developed third molars' forms, while identifying the most indicative signs for their classification.

Key words: teeth, third molars, orthopantomogram, retention, dystopia.

The work is a fragment of the research project "Age aspects of the structural organization of the immune system, the gastrointestinal tract and genitourinary system glands in norma and in pathology", state registration No. $0116 U 004192$.

Normally, as it is known, the eruption of the third molars completes the process of odontogenesis, as a result of which these teeth occupy the most extreme place in the remaining alveolar processes of the jaws $[3,4,7]$. They should be considered late not only because they erupt in delayed time, but also due to the late dates of their formation. This usually occurs in the 5th year of postnatal life, ie about one year before the complete eruption of the first permanent molar $[3,5,8]$. Naturally, the rudiments of the third molars go through the same stages of their development as other teeth, resulting in the formation of their crown sections, and then it is the turn of root development, which is associated with the process of teething. It should be noted that from the age of 8 calcification of the masticatory surface of the crown begins, at the 